\title{
Crítica da autonomia: liberdade como heteronomia sem servidão*
}

\author{
Criticism of Autonomy: Freedom as Heteronomy Without Servitude
}

\author{
Vladimir Safatle \\ Professor Titular do Departamento de Filosofia \\ Universidade de São Paulo [USP]
}

\section{RESUMO}

$\mathrm{O}$ artigo visa discutir formas de pensar o conceito de liberdade para além de sua submissão às figuras da autonomia. $\mathrm{O}$ objetivo é avaliar a necessidade e pertinência de pensarmos, em nosso contexto sócio-histórico, a liberdade como heteronomia sem servidão. Conceito este que nasce da crítica à elevação do paradigma do auto-pertencimento a condição de via única para a definição da liberdade.

\section{PALAVRAS-CHAVE}

Liberdade; Autonomia; Heteronomia; Propriedade de si; Auto-pertencimento.

\begin{abstract}
This article aims to discuss some strategies for thinking freedom beyond its submission to the notion of autonomy. The main goal is to evaluate the necessity and the relevance to think, in our socio-historical context, freedom as heteronomy without servitude. A concept that emerges from the criticism of the understanding of self-belonging as the only condition for defining freedom.
\end{abstract}

\section{KEY WORDS}

Freedom; Autonomy; Heteronomy; Self-ownership; Self-belonging.

Este artigo é fruto da aula magna apresentada como condição para a obtençáo do cargo de professor titular da FFLCH. 
Ó amigos, não mais esses sons.

Schiller

Para Eduardo Viveiros de Castro, Pela força das novas alianças

Trata-se aqui de discutir um modelo alternativo para pensar a liberdade enquanto horizonte regulador de processos de emancipação social. Tal modelo parte da tentativa de dissociar liberdade e autonomia, e gostaria de mostrar por que considero necessária essa dissociação. Partirei de uma crítica da autonomia enquanto estrutura normativa da efetivação de exigências de liberdade, o que significa colocar em questão o que poderíamos chamar de "perspectiva hegemônica da noção de emancipação" cuja força, como gostaria de mostrar, é indissociável da aceitação tácita de pressupostos metafísicos maiores, referentes à ideia de agência e, por consequência, de agência livre.

Haveria uma maneira mais natural de começar tal discussão, mas não é essa que será assumida. Pois poderíamos começar por fazer a longa história da elevação da liberdade a horizonte regulador fundamental da racionalização dos vínculos sociais e políticos no que convencionamos chamar de "Ocidente". Ela passaria pela emergência da noção de autogoverno e autolegislação enquanto motor de demandas de transformação social. A história de tal emergência, por sua vez, estaria vinculada necessariamente à reforma protestante com sua consolidação da interioridade ${ }^{1}$, com sua generalização do direito de resistência ${ }^{2}$, assim como estaria vinculada ao liberalismo e o respeito aos interesses particulares dos agentes econômicos. Por fim, à constituição política da noção de soberania popular através de uma longa história de revoluçóes que começa em I525, com as revoltas camponesas lideradas por Thomas Müntzer.

Mas contar essa história dessa maneira, mais uma vez, seria referendar o que não mais poderia ser referendado, a saber, a ilusão de que a emergência da emancipação como horizonte regulador de lutas sociais está vinculada, de forma privilegiada, à história social da Europa e de suas tensões internas. Seria uma maneira problemática de assumir uma narrativa que pressupóe o que poderíamos chamar um modelo de "universalidade concêntrica". Ou seja, tal como uma pedra jogada em um rio e que produz ondulaçóes na água a partir de um centro, a experiência da emancipação

\footnotetext{
1 Ver, a este respeito, a reconstrução proposta por Schneewind, 200I.

2 Já em Calvino encontramos uma afirmação como: "Os governantes de um povo devem envidar todo esforço a fim de que a liberdade do povo, do qual são responsáveis, não desvaneça de modo algum em suas mãos. Mais do que isso: quando dela descuidarem, ou a enfraquecerem, devem ser considerados traidores da pátria” (Calvino, 2009, p. 882).
} 
social teria um local de emergência que posteriormente contagiaria horizontes sociais geograficamente dispersos. ${ }^{3}$ Lugar que, não por acaso, seria eminentemente europeu. Como se o objetivo real dos processos de emancipação fosse nos transformarmos todos em "bons europeus".

Talvez a história da elevação da liberdade ao horizonte social regulador só poderia ser contada abandonando esse modelo concêntrico e arbóreo de universalidade que, mesmo falando em nome da emancipação, guardará necessariamente uma tonalidade colonial. Ao contrário, ela exigiria assumir um modelo no qual todas as formas sociais geograficamente dispersas são atravessadas por sistemas de possibilidade de emergência da emancipação. Mesmo conjugando tal possibilidade em gramáticas distintas, tais formas podem, em condiçôes específicas, entrar em ressonância, podem ser pensadas em ressonância. Em certas condiçóes, tais sistemas podem ressoar uns nos outros, criando outra forma de universalidade que poderíamos chamar de "universalidade por implicação lateral". "Implicação lateral" porque se trata de uma universalidade que nasce da possibilidade de implicação comum entre experiências que não têm uma matriz gerativa unificada, mas que se desdobram de forma autônoma umas em relação às outras, até que elas conseguem criar relaçóes de ressonância, permitindo a emergência de um processo global com múltiplos enraizamentos locais. E talvez estejamos em um momento histórico próximo a tal fenômeno.

Por isto, o que gostaria de fazer consiste em partir não da história da elevação da liberdade a horizonte regulador de nossas expectativas de transformaçáo social, tal como ela se configuraria no Ocidente, mas partir de seu ponto de esgotamento, de seu giro autocrítico. Eu gostaria de partir do fim. Ou seja, partir do momento em que nosso modelo hegemônico de liberdade é reflexivamente questionado no interior da própria tradição que o gerou.

É claro que tal estratégia exige, por sua vez, a aceitação de certos pressupostos. O primeiro deles é que poderíamos falar de "modelo hegemônico" nesse caso. Como se a multiplicidade dispersa de usos do conceito de liberdade acabasse por partilhar certos traços comuns. Traços estes que definem os limites dos efeitos pragmáticos, da força produtiva do uso do conceito. Obviamente, esta não é uma proposição imediatamente evidente. No entanto, gostaria de mostrar como ela pode ser sustentada.

Já o segundo pressuposto defende que um giro autocrítico da liberdade no interior do pensamento filosófico ocidental permite abrir um campo de ressonâncias com possibilidades de emancipaçáo presentes em formas sociais outras. O que poderia ser um passo importante para o que outros já definiram antes de nós como o exercício de descolonização de nossas formas de pensar e agir. Ou seja, o pressuposto aqui é:

3 Este é o modelo infelizmente presente na dialética do século XIX, principalmente na filosofia da história de Hegel (Hegel, 1986) e de Marx (basta lembrar das suas colocaçóes sobre a necessidade do imperialismo britânico na Índia e China, em Marx, 200o). 
nossas estratégias de autocrítica nos aproximam de possibilidades de emancipação não organizadas por uma matriz que se apresenta como colonizadora de pensamento.

Essa estratégia de partir do fim talvez explique a escolha em iniciar com uma colocação inesperada de Jacques Derrida, um dos autores que assumiram para si o diagnóstico de pensar a partir do esgotamento do modelo hegemônico de determinação da liberdade:

O que deve ser pensado aqui é esta coisa inconcebível ou incognoscível, uma liberdade que não seria mais o poder de um sujeito, uma liberdade sem autonomia, uma heteronomia sem servidão, em suma, algo como uma decisão passiva. Seria necessário, para isto, repensar os filosofemas da decisão e do par fundador da atividade e da passividade, assim como da potência e do ato (Derrida, 2003, p. 210).

Mesmo que Derrida não desenvolva o que propõe, ao menos não de forma explícita, aceitemos todo o peso deste "seria necessário", deste "o que deve ser pensado". Tentemos pensar isto que apareceria a nós como inconcebível e incognoscível, a saber, uma liberdade sem autonomia, uma heteronomia sem servidão. Inconcebível pois essas dissociações (liberdade sem autonomia, heteronomia sem servidão) parecem inicialmente a expressão simples de uma aporia. Entendemos de maneira quase natural a liberdade como uma capacidade de autodeterminação que se expressaria de forma preferencial através da força de legislar a si mesmo, de dar para si mesmo sua própria lei, em uma chave que nos remete inicialmente a Rousseau, para quem: "a obediência à lei que uma pessoa prescreveu para si mesma é liberdade" (Rousseau, 2006, p. 365). Neste sentido, ser movido por uma causalidade externa, heterônoma, aparece para nós como a figura elementar da sujeição, pois seria expressão do não estar sob a jurisdição de si mesmo.

Este filosofema protojurídico não tem realidade apenas moral. Ele é, ao mesmo tempo, central para a concepção do que entendemos por emancipaçáo política. Nossas lutas políticas parecem guiadas pela tentativa de realizaçáo social da autonomia, pela realização potencial de uma emancipaçáo que se realiza como força de autodeterminação em condiçóes de vida comum. Mesmo que tal emancipação seja o espaço socialmente garantido para a multiplicação de formas de vida singulares, tais singularidades partilhariam um atributo fundamental, a saber, elas seriam a expressão diferida de uma autonomia em ato que poderia fundar uma experiência coletiva marcada pela liberdade potencial, pela assunção da própria voz ou, ainda pela assunção daquilo que há de próprio na voz.

No entanto, talvez devamos nos questionar se tal concepçáo hegemônica de liberdade, longe de ser uma ideia reguladora fundamental para a definição do horizonte normativo das lutas sociais, não seria a expressão mesma de um bloqueio e da dependência a um conjunto tácito, não tematizado, de pressuposições metafísicas que esvaziam a capacidade de transformação de nossas ações políticas. Conjunto 
este que deve ser exposto e questionado caso queiramos construir um horizonte efetivo de transformaçóes sociais. Pois é possível que a paralisia atual em relação a tais transformaçôes seja também resultado de uma rede de dependências em relação a horizontes normativos não problematizados e, a sua maneira, partilhados pelas próprias formas de vida que gostaríamos de transformar. Não se trata simplesmente de afirmar que a paralisia política atual é fruto de um mero equívoco conceitual, como se fosse o caso de corrigir nossos conceitos para que tal paralisia seja suspensa. $\mathrm{Na}$ verdade, trata-se de expor a maneira com que somos radicalmente dependentes de formas de vida contra as quais aparentemente nós nos batemos. Produzir estranhamento naquilo que nos parece natural criando uma desidentificação generalizada em relaçáo a pressupostos naturalizados sempre foi uma operação decisiva para a reorientaçáo da açáo e para a abertura em direção a novas configuraçóes da práxis. A práxis só poderá se reorientar quando ela nascer de um horizonte geral de destituição em relação às coordenadas metafísicas que orientam e conformam tacitamente nossos desejos de transformaçáo. E possivelmente a mais forte de todas essas coordenadas metafísicas se encontra na naturalização de certo conceito de liberdade.

\section{Democracia e ipseidade}

Partamos então das articulaçóes propostas por Derrida. No início de seu livro, que é uma reflexão política sobre a democracia e seus impasses contemporâneos, Derrida parte de uma estratégia precisa: se quisermos entender o que está em jogo nas possibilidades inerentes à democracia, devemos tentar compreender que tipo de krátos, de força, de domínio, ela implica. Há um exercício da força que é próprio à democracia. Que força é esta e, principalmente, o que ela é capaz de produzir, qual sua plasticidade, qual é sua gramática própria?

Notemos o que esta estratégia pode nos abrir. Conhecemos diagnósticos sóciohistóricos que afirmam ser nossa democracia atual uma democracia sem demos. ${ }^{4}$ Neste sentido, a reflexão sobre o conceito de "demos", a recuperação do povo como categoria política central em sua força de deliberação seria a condição para a reconstrução da democracia. As múltiplas estratégias de fortalecimento das modalidades de emergência do povo aparecem assim como condição necessária para certa forma de revitalização de nossas aspiraçóes democráticas. ${ }^{5}$ No entanto se quisermos abrir a experiência democrática a uma superaçáo de seus limites atuais e permitir o advento de novos sujeitos políticos, podemos nos perguntar se a estratégia correta náo deveria focar em outro conceito, a saber, kratos. Pois se trata de perguntar se a verdadeira questáo não se encontra em saber qual sujeito ocupará os espaços de deliberaçáo e decisão, se a aristocracia ou o povo, se a soberania concentrada na mão de

\footnotetext{
4 Ver, por exemplo, Brown, 20I7. Para uma visão contrária, ver Colliot-Thélène, 20II.

5 Um modelo maior neste sentido é a recuperação da categoria de povo feita por Ernesto Laclau em Laclau, 20I5.
} 
um ou de muitos. Trata-se de perguntar se uma produção da democracia real não nos exigiria modificar radicalmente o que entendemos por "exercício do poder", o que significa exercer a força.

Estas questôes não são apenas relativas ao campo da filosofia política, como poderia inicialmente parecer. Não estamos apenas a falar de formas de governo quando nos perguntamos sobre que tipo de força é pressuposta pela "força do povo" que seria própria à democracia. Na verdade, estamos a falar sobre modos de constituição de agentes que querem ser socialmente reconhecidos como sujeitos. Todo sujeito é dotado de uma agência, esta agência pressupóe, por sua vez, alguma forma de força, uma dinâmica específica de decisão e exercício cuja configuração deve ser objeto de análise. A democracia implica, em seu horizonte normativo, certa forma de agente e de agência, mas que tipo de agente é este? Qual o sujeito da democracia e, principalmente, quais são suas pressuposições metafísicas naturalizadas? Como será possível criticá-lo e reconstituí-lo?

Estas questôes ganham importância em um contexto histórico, como o nosso, no qual o ceticismo em relação à democracia se amplia. É possível dizer que, à sua maneira, o texto de Derrida, escrito há mais de dez anos, é uma elaboração sobre tal ceticismo. Pois deveríamos nos perguntar se todas as formas de ceticismo em relação à democracia são iguais. São todas elas formas de regressão social vinculadas ao medo, as frustraçôes e ao ressentimento em relação às transformaçôes sociais e aos impasses econômicos inerente ao desenvolvimento do que costumamos chamar de sociedades democráticas? Ou há algumas delas que são autocríticas que visam liberar a democracia de pressuposiçôes metafísicas que seriam a verdadeira fonte de seus limites atuais, pressupostos estes que se perpetuam principalmente em sua versão liberal? Defender a democracia não seria atualmente possível apenas à condição de sermos capazes de criticar as pressuposiçôes metafísicas que ela naturaliza? Esta é, de fato, a verdadeira estratégia de Derrida.

A resposta a tais questóes passa pela compreensão de que a força do demos na democracia foi até agora indissociável de uma ipse. Trata-se de um krátos que é manifestação de uma ipse, de uma potência de realizar a condição de ser si mesmo. Poderíamos mesmo sugerir como definição: a democracia procura aparecer como o espaço social de manifestação da força de ser si mesmo. Sua racionalidade baseia-se na crença de que sujeitos partilham um desejo fundamental: o desejo de dotar-se da força de ser si mesmos. O que é, na verdade, apenas o começo do problema, não sua solução. Pois lembremos esta colocação astuta de Derrida:

Por 'ipseidade', eu subentendo pois algum 'eu posso' ou ao menos o poder que se dá a si mesmo sua própria lei, sua força de lei, sua representação de si, o coletivo soberano e reapropriador de si na simultaneidade da assembleia ou 
do estar em assembleia, do estar-junto, do 'viver junto' como se diz também ${ }^{6}$ (Derrida, 2003, p. 30).

Ipseidade, ser si mesmo, aparece aqui em uma declinação bastante significativa. Ela aparece indissociável da capacidade de dar para si mesmo sua própria lei, de representar-se a si mesmo e de estar em assembleia na condição de quem conserva para si sua própria força. O que pressupóe uma identidade fundamental entre a lei e o caso, entre a representaçáo e o representado, entre o estar junto e o estar em seu próprio domínio. Identidade esta que tem uma origem, princípio de imanência que se origina na sobreposição não tematizada entre um fundamento metafísico e um exercício político.

Tentemos entender melhor este ponto. Insistir que a democracia é o espaço social de manifestaçáo da força de ser si mesmo significa entre outras coisas que, por mais que uma sociedade democrática seja uma sociedade antagônica, caracterizada pelo reconhecimento da produtividade de conflitos sociais, acreditamos normalmente que a multiplicidade das perspectivas pode se incorporar em um demos, em um povo, nem que seja expulsando parte da população da condição de povo. Esta multiplicidade pode se incorporar em um demos porque o desdobramento da multiplicidade é a expressão de uma força que nunca sai de si. Em democracia, o povo é o nome deste movimento de atualizar o que nunca sai de si mesmo, de colocar em assembleia o que conserva sua própria determinação.

Pois o reconhecimento de conflitos sociais como motor da experiência política não implica, necessariamente, abandonar essa pressuposição unitária de base. Adorno já alertava para o fato da noção de conflito social pressupor a aceitaçáo tácita de uma gramática regulativa que orienta e preserva o campo de lutas sociais. Como ele dirá:

Os participantes deveriam ter reconhecido o sentido e a inevitabilidade dos conflitos e previamente concordado com as regras de conciliação do jogo uma condiçáo que elimina operacionalmente o caso crítico de os conflitos quebrarem as regras vigentes do jogo (Adorno, 1972, p. 8I).

Como se existisse uma espécie de jogo de linguagem de base no interior do qual a força que compóe o demos exerce sua unidade na multiplicidade de suas vozes. Essa preservação do campo de lutas não é apenas expressão de um pacto que preserva a integridade das vozes em conflito. Ela é a aceitaçáo de partilha de um comum que se manifesta em todos os polos em conflito, de uma gramática social de conflitos, com sua racionalidade imanente, que é a expressáo mesma de uma força do demos, convergente até mesmo em sua manifestação divergente. Uma força que, independente da configuração momentânea de seus conflitos, sempre afirmará a si mesma.

Mas é claro que esta força de ser si mesmo é animada por uma certa agonística. Pois afirmar si mesmo não é apenas uma constatação. É uma produção performativa

6 Para uma concepçáo distinta de ipseidade, ver Prado, 2017. 
que exige certa autoridade e força reconhecida. E é necessário força porque a afirmação de si mesmo é também uma capacidade de exclusão e ela não saberia ser de outra forma. Só é possível para mim ser mim mesmo se não houver nada que me retire da legislação de mim mesmo, nada que me coloque fora da jurisdição de mim mesmo, de meu próprio domínio. O exercício desta ipseidade é assim indissociável da constituição de formas de imunidade, de autoimunidade. ${ }^{7}$ Pois o poder que é uma ipse não saberia se afirmar sem se imunizar principalmente contra o que é involuntário, inconsciente, insubmisso a leis, contingente e que, por isto, só pode aparecer como um atentado potencial à liberdade. No entanto, estas figuras do involuntário, do inconsciente, do contingente não são apenas alteridades, elas são a potencialidade de um nomos outro, expressóes de outra ordem. Uma ordem que não se configura sob a forma da vontade, da consciência, da necessidade. Por isto, elas são a manifestaçáo de uma heteronomia que coloca em questão o que entendemos por agência, por atividade. Elas quebram a força que aparece como "minha".

Desta forma, esta força democrática que será também uma luta pela imunidade, uma decisão de imunizar-se, funda-se na defesa de que, quem age, age para afirmar seu próprio domínio e não é por acaso que ipse, como Benveniste mostrou bem, está associado a uma série relacionada ao poder, à possessão, à propriedade, à autoridade do senhor. Benveniste tenta explicar porque: "em várias línguas, 'o mestre' é designado pelo mesmo termo que 'si mesmo"” (Benveniste, I970a, p. 9) seguindo o desdobramento de * potis do sânscrito. Isto lhe permite mostrar como identidade e domínio estão sempre relacionados. O que é ipse está disponível na condição de possibilidade integral de uso, porque é expressão da minha habilidade de me dispor de mim mesmo.

Neste ponto, encontramos um pressuposto metafísico fundamental imanente à nossa noção de autonomia que, à sua maneira, contagia os usos que fazemos de conceitos que têm, na noção de autonomia, seu fundamento, como democracia, emancipação e liberdade. Pois seria importante chamar a atenção para o fato de a autolegislação e do autogoverno (processos simétricos neste contexto) estarem necessariamente fundados em um princípio muito mais decisivo e prenhe de consequências, a saber, a noção de autopertencimento como exercício paradigmático do autodomínio. ${ }^{8}$

Conhecemos uma multiplicidade de estratégias filosóficas distintas que pensarão a liberdade como forma precisa de autopertencimento. Poderíamos utilizar uma estratégia de leitura que irá explorar as distinçóes evidentes entre tais concepçóes mostrando, inclusive, como elas produzirão diferentes formas de vida e perspectivas críticas. Mas poderíamos também insistir que esta diferença, que esta dispersão ainda conserva um princípio comum que define certa limitação, que faz tal campo de

\footnotetext{
7 Para um desenvolvimento extenso deste paradigma imunitário, ver Esposito, 2002.

8 Sobre o conceito de autopertencimento, ver sobretudo Cohen, 1995. Ou, para uma visão libertária do problema, ver Nozick, 1974.
} 
diferenças girar em torno de uma dificuldade comum e aparentemente insuperável. ${ }^{9}$ Dificuldade aparentemente insuperável ao menos para nós, leitores de tais experiências de pensamento às voltas com as possibilidades históricas inerentes às sociedades capitalistas contemporâneas. Pois a questão fundamental aqui será: quais são as formas sociais atuais que configuram e definem as possibilidades de realizaçáo de demandas de autopertencimento? Para nós, o que significa ler e tentar recuperar formas diversas de autopertencimento como modelo de realização da liberdade?

Se aceitarmos que a liberdade não pode ser compreendida apenas como um exercício de expressão individual, mas que ela é, na verdade, um modo de relação social, então será importante nos perguntarmos como certos conceitos filosóficos vinculados à estruturação normativa da noção de liberdade podem ser atualmente significados. Isto dá a atividade filosófica um caráter estratégico que é constitutivo de sua natureza histórica. Há situaçóes históricas nas quais certos conceitos não podem mais ser postos, isto se quisermos conservar o potencial de emancipação que eles um dia foram capazes de expressar. Há certas coisas das quais não podemos mais falar, se quisermos realizá-las. É possível que tal pressuposição valha para as múltiplas e diversas formas de liberdade como autopertencimento.

\section{Autonomia e pertencimento de si}

Voltemos então por um instante àquilo que poderíamos chamar de "concepção hegemônica de autonomia”. Atualmente, aceitaríamos sem maiores problemas que uma das características fundamentais dos sujeitos reconhecidos como dotados de autonomia moral é exatamente o autopertencimento. Para ser o legislador de mim mesmo, para ser o enunciador da lei que expressa minha liberdade é necessário que esta lei seja minha. Se ela fosse, por exemplo, lei de um Outro que internalizei, lei que se impôs a mim através da coação, ela seria expressão da minha servidão, não da minha liberdade. Quando a lei se exerce, seu exercício implica a constituição de um espaço no qual eu não posso me perder, um espaço no qual eu não pertenço a ninguém, a não ser a mim mesmo. Por isto, Kant, por exemplo, insistia que a causalidade presente na ação autônoma é uma causalidade através da liberdade (Kausalität durch Freiheit) ${ }^{10}$. Esta liberdade é outra maneira de dizer que há uma espécie de mesmidade implicada no exercício da autonomia. Liberdade como autonomia não é apenas se afirmar para além da causalidade da natureza e das disposiçóes mecanicistas que aparentemente submeteriam tudo o que é objeto, tudo o que é coisa. Liberdade como autonomia é estar em possessão de si mesmo, em possessão de meus atos, de minhas razóes para agir.

\footnotetext{
9 Eu mesmo procurei fazer isto ao mostrar como Michel Foucault ainda partilhava a noção de liberdade como auto-pertencimento. Ver Safatle, 20I6.

${ }^{10}$ Kant, 20I6, p. 72.
} 
Normalmente, associamos autonomia a uma capacidade fundamental de autorreflexão. Dizemos então que um sujeito autônomo é alguém capaz de tomar a si mesmo como objeto de inspeção e reflexão. Mas lembremos que através do ato de tomar si mesmo por objeto de autorreflexão eu exercito a possessão de mim mesmo. Pois através da autorreflexão eu objetifico o que em mim é ainda afetado por uma causalidade externa. Eu objetifico no sentido de "dispor diante de mim", de tomar possessáo de algo por colocá-lo diante de mim. No mesmo movimento, eu tomo distância do que me causa fora de meu próprio domínio e afirmo o primado de decisóes enunciadas em um espaço no qual se exerce uma relação sem distâncias a mim mesmo. Neste espaço sem distância, eu experimento o que "eu" significa, para além de sua realidade puramente psicológica.

É neste ponto que gostaria de introduzir o argumento central deste artigo, a saber, tal noção de autonomia tem como pressuposição maior não apenas as relaçóes de autopertencimento, não apenas a autoidentidade, mas o direito natural da propriedade de si. Náo é apenas como dotado de autopertencimento, mas como proprietário de si mesmo que o sujeito autônomo age e afirma sua liberdade. Pois nas condições históricas atuais não é possível insistir em uma forma de pertencimento que não seja expressa sob o regime da propriedade. No interior de nossas sociedades capitalistas, todas as formas de pertencimento e possessão foram colonizadas por uma forma geral expressa nas relaçóes de propriedade. Não seria possível a uma reflexão própria a filosofia política ignorar tal situação. Não seria possível ignorar que existe algo como uma força metafísica do capitalismo, ou seja, um modo de conformação das possibilidades gerais de existência e de relação através da generalização de uma ontologia de propriedades que organiza até mesmo nossas formas de luta e de resistência. Até mesmo o vocabulário de nossas lutas é conjugado no interior de uma ontologia de propriedades, na qual é questáo sempre de explicitar o que me seria "próprio", o que seria "meu".

Mesmo quando a democracia liberal foi criticada do ponto de vista da defesa dos bens comuns, tal crítica foi feita normalmente em nome de outra forma de propriedade, de outra forma de possessão, a saber, a propriedade coletiva. ${ }^{11}$ Raros foram os momentos nos quais tal crítica foi feita em nome da possibilidade de circulaçáo do que é impróprio, do que não é configurado como propriedade. Isto demonstra como boa parte de nosso esforço crítico permaneceu no mesmo horizonte normativo que fundamenta o que gostaríamos de criticar.

De fato, a definição da liberdade como propriedade de si é uma das origens históricas da noção moderna de autonomia. Todos conhecemos a afirmação de Locke no Segundo Tratado do Governo, de I689.

${ }^{11}$ Para um modelo de crítica baseado na despossessão, ver Agamben, 2014. 
Embora a terra e todas as criaturas inferiores sejam comuns a todos os homens, ainda assim todo homem tem a propriedade em sua própria pessoa. A este ninguém tem direito algum, a não ser ele próprio. Pode-se dizer que o trabalho do seu corpo e a obra de suas máos sáo propriamente seus. Tudo o que ele retire do estado que a natureza providenciou e lá deixou fica misturado ao seu trabalho, justando-se a algo que lhe pertence e, por isto, fazendo dele sua propriedade (Locke, 2003, p. 287-288).

Ou seja, a propriedade individual do que aparece previamente como um bem comum (a terra e todas as criaturas inferiores) é baseada no fato do trabalho ser, ao mesmo tempo, uma expressão de si e forma de possessão. $\mathrm{O}$ trabalho aparece aqui como a produção do que é próprio a mim, do que é a confirmação especular de minha própria determinação. Como o burguês que tem dentro de sua casa objetos que contam a história de sua pessoa, de suas pequenas idiossincrasias, viagens exóticas e memórias, a consciência que trabalha parece querer transformar a natureza em uma grande home decorada por objetos que são a expressão de sua própria história. Pois propriedade é, acima de tudo, um afeto: o afeto da segurança das coisas que estão completamente submetidas ao meu domínio. Esta sobreposição entre expressão e possessão pode ocorrer porque a forma da autodeterminação, o campo de nossa ipse é imediatamente a expressão de relaçóes de propriedade. Eu sou sujeito porque tenho a propriedade de minha própria pessoa.

Lembremos como esta definição de liberdade como propriedade de si aparece explicitamente antes de Locke, no interior das lutas políticas da Inglaterra do século XVII. Dentre tantos exemplos possíveis, tomemos a maneira com que Richard Overton inicia, em I646, seu panfleto An arrow against all tyrants and tyrany, peça maior da batalha dos Levellers, movimento considerado como um dos primeiros a apresentar a consciência emergente do radicalismo democrático:

Para todo indivíduo na natureza é dada uma propriedade individual por natureza que não pode ser invadida ou usurpada por ninguém. Para todos, na medida em que é si mesmo, haverá a propriedade de si, se não ele não poderia ser si mesmo; e a este respeito nenhum terceiro pode privá-lo sem uma violaçáo manifesta e uma afronta ao princípio básico da natureza e das regras de equidade e justiça entre homens. Meu e teu só podem existir desta forma. Nenhum homem tem poder sobre meus direitos e liberdade, e náo tenho poder sobre direitos e liberdade de homem algum. Posso ser apenas um individuo, gozar de mim mesmo e de minha propriedade de si, mas não tenho o direito de ser mais do que mim mesmo; se faço isto entro e invado os direitos de outro homem, o que náo tenho direito de fazer. Pelo nascimento natural todos os homens são iguais e identicamente nascidos para gozar da propriedade, da liberdade e como somos entregues por deus, por intermédio da natureza, neste mundo, todos têm uma liberdade inata, natural e propriedade - como está escrito nas tábuas do coraçáo de todos os homens (Overton, 1998, p. 55). 
As colocações aqui são exemplares. $\mathrm{Na}$ aurora do conceito moderno de democracia, Overton proclama a liberdade como reconhecimento de uma relaçáo de propriedade da qual náo posso ser privado, da qual nenhum poder pode me alienar. Daí a noção da propriedade de si como um direito natural. Este direito natural deve fundamentar a institucionalidade da vida social garantindo um espaço no qual a ação social é pensada como o exercício das demandas de reconhecimento da minha condição de proprietário. Como Macpherson afirmou:

$\mathrm{O}$ indivíduo não tem apenas a propriedade em sua própria pessoa e capacidade, uma propriedade no sentido de um direito a usufruir e usá-las e excluir outros deste usufruto. Na verdade, é esta propriedade, esta exclusão dos outros que faz de um homem um ser humano (Macpherson, I993, p. I42).

Esta maneira de afirmar a experiência da liberdade não poderia deixar sentir as consequências de um paradoxo. Pois relaçóes de propriedade são, normalmente, relaçóes entre pessoas e coisas, ou seja, elas são exatamente o contrário do que entendemos por relaçóes capazes de produzir a afirmação da condição de sujeitos. Relações de propriedade pressupóem esta distinção fundamental entre o que se submete a um direito de uso (coisas) e o que não se submete (pessoa). ${ }^{12}$ Por isto, elas são dissimétricas e baseadas em submissão, o proprietário tem direito de uso sobre sua propriedade. $\mathrm{O}$ que é propriedade está em relação de dependência existencial em relação a seu proprietário. Ou seja, a causalidade de uma propriedade lhe é necessariamente exterior. Ela se encontra na vontade de seu proprietário. No entanto, por estar no interior do domínio de seu proprietário, a propriedade tem uma peculiar identidade ao seu proprietário. Por ser propriedade, o que lhe ocorre, ocorre imediatamente também ao proprietário.

Ninguém melhor que Hegel em sua dialética do senhor e do escravo demonstrou como havia uma reversibilidade contínua na relação aparentemente dissimétrica entre propriedade e proprietário ${ }^{13}$. Sua dialética do senhor e do escravo pode ser lida como uma astuta crítica a formas liberais de liberdade. Pois Hegel lembrará que o uso da propriedade implica, necessariamente, transformação do próprio proprietário, dependência do próprio proprietário (senhor) em relação à propriedade (escravo), em relação ao modo de existência da propriedade. Como o gozo do sujeito proprietário depende da propriedade e de seu modo de existência, é impossível que esse modo de existência não passe necessariamente no sujeito.

Hegel pode lembrar desta reversibilidade porque, ao menos em sua Fenomenologia do Espirito, as relaçóes de propriedade não aparecem apenas como relaçóes de uso, mas como relaçóes de desejo. Eu não apenas uso propriedades, eu desejo o que se reduz à condição de propriedade e esta é a base do processo de alienação inerente a

\footnotetext{
${ }^{12}$ Ver, a este respeito: Esposito, 2014.

${ }^{13}$ Cf. Hegel, I992, capítulo IV. Sabemos da crítica hegeliana à generalização das relações de propriedade também pela parte dedicada ao direito abstrato em Hegel, I970.
} 
toda noção de propriedade de si. Meu desejo se submete à forma da propriedade, meu ser se determina no interior de um campo de propriedades. Eu me determino a partir daquilo que se conforma à condição de propriedade. Desta forma, desejar como um senhor de escravo é definir o escravo como o modo de existência do meu desejo, é vincular minha expressão ao que se dispóe integralmente, ao que se define de forma unidimensional, ao que náo pode escapar de minha possessão, mas que apenas confirma meu domínio, minha narrativa sobre mim mesmo. Isto traz consequências maiores quando falamos de uma relaçáo de ipseidade. Pois o conceito de propriedade de si impede que a liberdade seja distinta de um procedimento de autorreificação.

A tese que gostaria de defender aqui é que tal noção de propriedade de si não é apenas uma construçáo ideológica que à sua maneira sublima as condiçóes de reprodução material da sociedade capitalista de livre-mercado em ascensão. Se eu me servi inicialmente das consideraçôes de Derrida foi para insistir na tese da liberdade como propriedade de si ser também a realização possível de uma premissa metafísica que se enraíza em nossas elaboraçóes mais originárias sobre si mesmo e autopertencimento. No entanto, a partir do momento que tal noçáo de liberdade como propriedade de si emerge, todas as outras formas de autopertencimento ficam impossibilitadas. Pois ela tem ao seu favor a força dos processos de reproduçáo material da vida e de sua colonização extensiva das possibilidades imanentes à experiência social.

Ou seja, há uma tese de base no meu argumento e ela poderia ser descrita como a defesa de uma certa forma de "impossibilidade retroativa". Eu defendi que várias concepçóes distintas de liberdade partilhavam, cada uma à sua maneira, o princípio de autopertencimento como dispositivo fundamental de especificaçáo. Essa concepção, "ser livre é pertencer a si mesmo", organiza os usos da noção de autonomia tanto no campo moral quanto no campo político. No entanto, se o capitalismo é algo mais do que um sistema de trocas econômicas, se ele de fato é uma gramática de relaçôes sociais, então seremos obrigados a assumir que no seu interior certas operaçôes tornam-se gramaticalmente impossíveis. Uma delas será distinguir autopertencimento e propriedade de si.

É neste ponto que devemos retomar a colocação inicial de Derrida, é neste horizonte sócio-histórico que devemos compreendê-la. Na verdade, sua afirmação é resultante de uma decisão estratégica. Pois trata-se de defender simplesmente náo ser mais possível pensar a liberdade como autonomia, nos restando a tarefa maior de compreender o que pode ser uma liberdade como heteronomia sem servidão. Mas há também de insistir que este horizonte metafísico faz da democracia, ou ao menos fez dela até hoje, a afirmação do primado das relaçôes de propriedade, da constituição da agência social como expressão da propriedade de si. Em suma, a democracia foi até agora a afirmação do ser proprietário de si mesmo. Ela foi até agora a defesa da integridade da pessoa como proprietária de si. 


\section{Um outro kratos para o demos}

Tentemos pois descrever, ao menos de forma geral, o que poderíamos entender como heteronomia sem servidão. Há várias maneiras de introduzir esta questão vinculada à consciência historicamente crescente de um potencial moral e político fundamental presente na defesa de uma agência causada pelo que não se deixa determinar como o que me é próprio.

Gostaria de começar sugerindo uma definição operacional sobre o que é uma heteronomia como servidão. As relaçóes de heteronomia são vivenciadas como servidão quando elas expressam a submissão da minha vontade à vontade de um $\mathrm{Ou}$ tro. Nesta condição, e apenas nesta condição, a heteronomia é uma forma de alienação, já que é apenas nesta condição que o exercício da força é pensado como realização de uma dominação. Mas há situaçóes nas quais me implico com aquilo que, mesmo não me sendo próprio, mesmo não se definindo a partir do exercício das potencialidades da minha pessoa, também não é vontade de um Outro. ${ }^{14}$ Isto implica capacidade de se relacionar àquilo que, no Outro, o despossui de si mesmo, recusando a forma geral da vontade, ou seja, que despossui não só a mim, mas também o Outro. Deixo-me afetar por algo que me move como uma força heterônoma e que, ao mesmo tempo, é profundamente desprovido de lugar no $\mathrm{Ou}$ tro, algo que desampara a mim e o Outro. Assim, constitui-se uma relação que não pode ser descrita como servidão, mas que é paradoxalmente uma forma de liberdade.

Pode-se estranhar falar em liberdade neste contexto. Mas comecemos por perguntar: tudo o que causa minhas açóes de forma involuntária, tudo o que quebra a jurisdição das leis que um dia pareci dar para mim mesmo é, de fato, um atentado à minha liberdade? Não haveria entre nós uma concepção de liberdade para a qual sou livre quando sou capaz de me abrir àquilo que não controlo completamente, àquilo que não se submete à lei que tomei por minha e que me aparece como involuntário, como contingente, como inconsciente? Esta outra concepção não dirá que liberdade é autonomia. Ela dirá que liberdade é saber que há sempre uma alteridade profunda que me afeta e me transforma, que por isto minhas ações nunca são completamente minhas. Pensar assim nos deixaria mais aptos a ouvir aquilo que nos atravessa sem nunca adquirir a forma de nós mesmos. Esta é uma maneira possível de compreender o que está em jogo em afirmações de Judith Butler, para quem, no interior de vínculos sociais:

Nós somos despossuídos de nós mesmos em virtude de alguma forma de contato com outro, em virtude de sermos movidos e mesmo surpreendidos ou desconcertados por este encontro com a alteridade. A experiência em si não é simplesmente episódica, mas pode e dever evelar uma base de relacionalidade - nós não simplesmente movemos nós mesmos mas somos movidos por

\footnotetext{
${ }^{14} \mathrm{O}$ modelo desta implicação é dado pela relação entre sujeito e objeto causa do desejo em Jacques Lacan. Para tanto, ver Lacan, 2000.
} 
aquilo que está fora de nós, por outros, mas também por todo "fora" que resida em nós (Butler \& Athanasiou, 2013, p. 3).

Ou seja, entrar em relação não é apenas confirmar-se em suas propriedades supostas, mas despossuir a mim mesmo por me abrir a algo me afeta vindo de uma exterioridade. Tal despossessão expóe minha vulnerabilidade estrutural aos encontros, assim como a opacidade a mim mesmo daquilo que me leva a vincular-me a outros que me despossuem e me descontrolam. Por isto, a relacionalidade própria à condição humana não pode ser compreendida como garantia de cooperação. Que a despossessão possa aparecer também como expressão máxima de uma vulnerabilidade produzida pela insegurança social e civil a ser politicamente combatida com todas nossas forças, já que produção de um não-ser social, isto não elimina a necessidade de uma política capaz de quebrar a substancialização do "individualismo possessivo" através da afirmação da produtividade de situaçóes de heteronomia sem servidão.

Desta forma, devemos dizer que, em uma democracia efetiva, uma democracia ainda por vir, os agentes estaráo em contínua despossessão de si por serem capazes de implicar-se com aquilo que desconstitui o sistema de determinação da pessoa e de suas propriedades. A democracia efetiva não é a afirmação da propriedade de si. Ela é a emergência de sujeitos políticos desprovidos de relação de propriedade, mesmo de propriedade de si. Mas esta despossessão de propriedades é a condição para que eles encarnem processos que retiram continuamente os indivíduos de suas identidades supostas criando um campo de implicação genérica. Há uma plasticidade social no interior da democracia efetiva que ainda náo conhecemos. Pois isto nos exigiria afetos políticos diferentes daqueles que nos orientam atualmente.

Mas tentemos entender melhor o que significa dizer que, em uma democracia efetiva, os sujeitos estarão em contínua despossessáo de si. Uma forma de pensar tal problema passa pela tentativa de compreender o que pode ser um kratos que náo seria mais a expressão da afirmação proprietária da autoidentidade. Vamos inicialmente lembrar algumas características semânticas do termo kratos. Se seguirmos novamente Benveniste ${ }^{15}$, veremos que inicialmente kratos significa força ou poder. Mas os termos gregos para força são vários: bia, is, iskhús, sthénos, alké, dúnamis. Qual então a especificidade da força que é kratos. Começando por algumas relaçôes com alké, Benveniste nos lembra que kratos era normalmente ligado à superioridade daquele que afirma sua força sobre outros. Pode se tratar da superioridade física, superioridade em combate, mas também de superioridade na assembleia, no exercício do poder próprio ao rei ou chefe. Há pois dois valores em kratos: "superioridade, prevalência" em um teste de força e "poder de autoridade". Esses valores denotam uma qualidade de herói.

No entanto, ao passarmos do nome kratos para o adjetivo kraterós, uma mudança significativa ocorre. Pois o adjetivo pode também significar "duro, cruel, violento"

\footnotetext{
${ }^{15}$ Benveniste, I970b.
} 
em um sentido que está longe de ser uma qualidade, indicando ao contrário o que causa sofrimento, dor e destruição. Benveniste chega a falar de dois grupos semânticos que devem ser vistos separadamente. Se o primeiro designa uma qualidade política e moral que compóe a mestria, o segundo nunca se desenvolve em direção a qualidades desta natureza. A sabedoria dos gregos colocou juntamente atividade política e exercício da crueldade, a imperiosa submissão à vontade de um outro. A afirmação da autoridade aparece como uma sujeição sempre possível à vontade do outro.

Mas o que poderia ser um kratos liberado da crueldade? Nós conhecemos a estratégia liberal de recusar qualquer outra força comum que não seja o contrato, a associação entre forças individuais. No entanto, tal estratégia nos previne de questionarmos outra forma de crueldade, a saber, a crueldade necessária para reduzir a existência às formas possíveis do que sempre aparece como objeto da propriedade individual. Acabamos por esquecer de nos perguntarmos se a maior de todas as crueldades não exatamente seria esta que nos leva a aniquilação do indivíduo, mas à redução das formas de existência e do exercício da força às formas da autonomia individual, ao exercício dos interesses que são constituídos como representaçóes da consciência.

\section{A emancipação das coisas}

Pensemos pois este kratos liberado das formas da crueldade em três níveis de relaçóes sociais, a saber, as relaçóes aos objetos, as relaçóes aos sujeitos e as relaçóes a si. O primeiro destes níveis, a saber, as relaçôes aos objetos, é normalmente o nível mais negligenciado quando se é questão de reflexôes a respeito das dinâmicas de emancipação. Pois estamos profundamente colonizados pela ideia de que o trabalho produz o direito de possessão. Aquilo no qual eu trabalho é meu. Um povo, como um sujeito político coletivo, como um trabalhador coletivo, deveria também aparecer como o proprietário dos objetos nos quais ele trabalha. Seguindo tal esquema, a emancipação social só poderia se compreender como o ato de tomar possessáo dos objetos cuja fonte de existência são o meu trabalho ou o trabalho do povo do qual faço parte.

Ou seja, "coisas" aparece aqui como o que está a serviço de "pessoas", como o que pode ser submetido a uma relação de propriedade personalizada. Vemos aqui uma forma de emancipaçáo que não escapa da generalização das relaçóes de propriedade e de usufruto conectado à propriedade. Neste sentido, podemos dizer que apenas em uma sociedade de proprietários, em uma sociedade na qual o estatuto fundamental de membro confunde-se com o estatuto de proprietário, podem existir "coisas". Nas sociedades nas quais "pessoas” são livres, o preço a pagar por tal liberdade é que as "coisas" estejam sujeitas à servidão. Assim, se São Tomas afirmava que "pessoa" era o espaço no interior do qual a razáo podia expressar o domínio de seus 
próprios atos ${ }^{16}$, como o autor de seus próprios atos, não sendo levado por outro, é porque, para nós, as coisas não agem, elas são ativadas por nós.

Mas podemos perguntar se o verdadeiro conceito de emancipação social não seria exatamente a noçấo de uma sociedade de sujeitos livres, mas uma sociedade de sujeitos e coisas livres. Pois é possível que a emancipação das coisas seja a primeira condiçáo para a emancipaçáo dos sujeitos, o que nos obrigaria a aceitar a existência de um kratos que vem das coisas, que é a afecção das coisas em sujeitos a partir de uma dimensão involuntária e externa.

Por outro lado, falar de emancipação das coisas significa que, longe de serem instrumentos de afirmação das relaçóes de possessão, as coisas podem aparecer como o que nos causa e como o que age em nós sem estar vinculada à vontade de uma pessoa, à deliberaçáo de uma consciência. Um pouco como essas obras de arte que nos afetam sem serem a expressão da deliberação de uma pessoa. Pois elas não são apenas a sedimentação dos circuitos de histórias que as compóem, nem o resultado da expressão egológica de seus "autores”, mas elas são também a força de seus corpos, de seus materiais, dos caminhos de suas materialidades, de sua "vida própria". Um kratos liberado da metafísica da propriedade seria o reconhecimento da força das coisas em nós, em nossas açóes.

O exercício de tal kratos pode ser a condição para uma sociedade na qual coisas nos afetam em sua impropriedade e inapropriação. Estamos a falar de uma sociedade na qual as coisas seriam inapropriáveis, na qual eles não seriam nem propriedade individual nem propriedade coletiva, mas a expressão de que vivemos em um circuito de objetos que nos afetam e não nos são próprios. Uma sociedade democrática seria aquela na qual as coisas não existem mais na forma do que poderia ser possuído. Nenhuma reconstituição da biopolítica que nos governa pode se realizar sem começar pela destituição da centralidade das relaçóes de propriedade na definição da vida social.

Isto interfere na própria noção do que entendemos por "sujeito". Pois sujeitos teriam as marcas dos objetos que lhes afetam e que eles portam. Os sujeitos trariam um núcleo do objeto em si mesmos, o que modifica radicalmente o que entendemos por "si mesmo". Esta emergência de novos sujeitos políticos é inseparável da emergência de um sujeito descentrado, sujeitos descentrados pelo que aparece a eles como involuntário, contingente e opaco, como um objeto. Tal descentramento nos obriga a repensar os paradigmas da decisão e da deliberaçáo como cálculo de meios e fins que nos acompanha desde Aristóteles (boulesis). Ele nos obriga a colocar em questáo o peso metafísico de distinçóes como as que nos leva a afirmar que: "o ato forçado mostra-se ser aquele cujo princípio é exterior, a pessoa forçada em nada contribuindo ao princípio da ação" (Aristoteles, 2008, III 2, b I5). Pois sujeitos capazes de se livrar de tal distinção não deliberam, eles assumem para si uma força imprópria que os colocam à deriva. A natureza exterior do princípio do ato não é vista mais como

${ }^{16}$ Aquino, 1998, vol. I, Q. 29, art. I. Para um desenvolvimento importante deste ponto, ver Esposito, 2013, p. II3. 
limitação da liberdade, mas como afirmação de um processo de subjetivação de força não compreendida mais como o exercício do ser si mesmo.

\section{Revoluções e horizontes descoloniais}

Deixe-me dar um exemplo do que procuro descrever. Jules Michelet um dia afirmou que "Toda revolução é um lance de dados". Esta era uma bela maneira de dizer que a aceitação do conceito de revoluçáo nos obrigaria repensar os filosofemas da decisão, da agência, por fim, da consciência diante dos processos revolucionários. Neste sentido, é interessante lembrar como alguém como Hannah Arendt verá nisto um certo paradoxo:

Era como se uma força maior do que o homem interviesse no momento em que os homens começavam a afirmar sua grandeza e a defender sua honra [...] As várias metáforas que mostram a revolução não como uma obra dos homens, mas como um processo irresistível, as metáforas de ondas, torrentes e correntezas, ainda foram cunhadas pelos próprios atores, que, por mais que tivessem se inebriado com o vinho da liberdade em abstrato, visivelmente não acreditavam mais que fossem agentes livres (Arendt, 1994, p. 8I).

Como se vê, o paradoxo aqui ficaria por conta de um fenômeno, feito em nome da liberdade e da autonomia dos indivíduos, ser pensado como a submissão a uma força incontrolada, comparável a fenômenos naturais como ondas, correntezas e turbilhōes. Sim, para Arendt os únicos fenômenos políticos de transformação seriam aqueles que confirmam a forma prévia dos indivíduos portadores de interesses e capazes de deliberar através da consolidação de sua vontade autônoma. Há uma psicologia na base desta avaliação política, há uma antropologia no fundamento normativo desta avaliaçáo de processos históricos. É esta psicologia que talvez decaia quando uma revolução eclode. Por isto, talvez devamos levar a sério a possibilidade do espanto de Arendt vir do fato das revoluçóes serem exatamente a emergência de outra forma de kratos, de outra força cuja matriz mereceria uma análise mais detalhada. Isto nos coloca questôes fundamentais a respeito do que significa, afinal, uma ação revolucionária. Quem age e, principalmente, como se age? Agimos como quem executa um plano a ser realizado ou como quem aceita entrar em um movimento incontrolado de deriva? Aqueles que produzem revoluçóes sabem que estão a fazêlo e o que estão a fazê-lo ou sáo aqueles que aceitam ser suportes de um processo sem horizonte definido?

Esta é uma maneira de dizer que a emergência de sujeitos coletivos vinculados à afirmação de autonomia de grupos outrora violentados não implica necessariamente na realização de processos emancipatórios. Se continuarmos a pensar a emancipação a partir do paradigma da maturação, do alcançar a condiçáo de sujeito de direitos, então teremos a impressão de que a submissão do sujeito à forma do indivíduo portador de direitos e reconhecido em sua maturidade implica transformaçôes sociais 
estruturais. Com se o problema central da vida social estivesse ligado ao pretenso fato de nem todos sujeitos serem completamente indivíduos, nem todos terem alcançado uma individualidade desejada e compreendida como horizonte antropológico geral de emancipação. ${ }^{17} \mathrm{Ou}$ seja, como se a base normativa de nossas lutas sociais estivesse vinculada à possibilidade da generalizaçáo de um modo de existência social caracterizado pela agência racional entendida como capacidade de deliberaçáo e maximização de interesses, tal como vemos no indivíduo moderno. $\mathrm{O}$ indivíduo como modo de existência é geralmente visto como um solo pré-político do político e é este ponto que deve ser discutido.

Por fim, um kratos não mais conectado à força de permanecer idêntico a si mesmo seria o exercício de agir a partir do que nos despossui. Isto significa agir a partir do que desconstitui nossa formação como povo. Pois essa força não constitui uma identidade coletiva, nem uma interdependência baseada na solidariedade necessária diante do reconhecimento de nossa vulnerabilidade. $\mathrm{Na}$ verdade, a política pode se tornar o espaço da desconstituiçáo de identidade e da emergência de um comum que não é apenas a extensão ilimitada do potencial das relaçóes humanas. Política como a integração do que até então fora compreendido como não-humano, como coisa, como animalidade. Um pouco como essa implicação genérica presente no pensamento ameríndio. Nesse mesmo pensamento no qual a cultura fornece a universalidade de um espaço de imbricação contínua entre humano e natureza. Espaço no qual:

Todos os animais e demais componentes do cosmo são intensivamente pessoas, virtualmente pessoas, porque qualquer um deles pode se revelar (se transformar em) uma pessoa. Não se trata de uma mera possibilidade lógica mas de potencialidade ontológica (Viveiros de Castro, 2017, p. 47).

Nesta cosmopolítica, todo existente, sejam homens ou animais, participa da mesma humanidade. Os animais têm almas como nós, para os ameríndios, mesmo um europeu pode ter alma (o que náo era um raciocínio reversível). O que difere são seus corpos, que estabelecem perspectivas singulares baseadas em sistemas específicos de afecções. Assim, uma multiplicidade de corpos pressuporá uma multiplicidade de perspectivas sob a univocidade de uma mesma humanidade. Contrariamente ao nosso multiculturalismo, aparece pois um peculiar multinaturalismo no qual vários conceitos de natureza cortam o plano de um mesmo campo da cultura.

Esta univocidade da cultura, tão estranha a nossa sensibilidade atual que só saberia ver nisto um narcisismo animista, permite, ao contrário, uma operação generalizada de descentramento. Se a mesma humanidade está presente nos homens e animais, então nada é humano inequivocamente. Ser humano é, na verdade, estar constantemente fora de si, ser um anti-Narciso, já que:

${ }^{17}$ A este respeito, ver sobretudo Zaharijevic, Against individual: who qualifies as "one"? (no prelo). 
Muito ao contrário de nossas fantasias a respeito do paraíso narcísico dos povos exóticos (a antropologia versão Disney), a pressuposição radical do humano não torna o mundo indígena mais familiar nem mais reconfortante: ali onde toda coisa é humana, o humano é 'toda outra coisa' (Viveiros de Castro, 2017, p. 54)

E talvez nesse ponto encontremos o sistema de ressonâncias que nos permite aproximar o giro autocrítico do pensamento filosófico ocidental e o potencial emancipatório presente em sociedades não-ocidentais e não-capitalistas.

Para concluir, seria necessário levar em conta o fato de tais proposiçóes soarem muito genéricas para alguns. Mas há de se argumentar que isto não é um problema. Adorno costumava dizer que a antecipação da forma de uma sociedade reconciliada era um atentado contra a própria reconciliação. Pois os sujeitos mutilados que somos não podem imaginar o que é a liberdade social sem se servir de modelos de organização próprios à situação de guerra civil na qual vivemos em nossas lutas cotidianas de classe, em nossas lutas cotidianas contra a violência próprias às nossas democracias liberais. Calar-se diante do que pode ser o governo de outro kratos não é impotência, mas confiança na força plástica da política e de sua multiplicidade local. A teoria pode nos levar a acreditar que temos o desejo e a capacidade de fazer muito mais do que fizemos até agora, a teoria pode nos dizer que não fomos ainda muito longe com nossa negação, mas ela náo pode antecipar o que recusa toda projeção. Porque a teoria se abre diante do que apenas a prática emancipada em seus contextos locais pode produzir.

\section{Referências bibliográficas}

AgAmBEN, G. (20I4). Altíssima pobreza: regras monásticas e formas de vida. Tradução de S. Assman. São Paulo: Boitempo.

AdORnO, T. (1972). Soziologische Schriften. Frankfurt: Suhrkamp.

Aquino, T. (1998). Suma teológica. Petrópolis: Vozes.

AREndt, H. (1994). Sobre a revolução. São Paulo: Companhia das Letras.

ARISTÓteles. (2008). Ethica Nicomachea I I3 - III 8. São Paulo: Odysseus.

Benveniste, E. (1970a). Vocabulaire de termes indo-européens, v. I. Paris: Gallimard.

Benveniste, E. (1970b). Vocabulaire de termes indo-européens, v. II. Paris: Gallimard.

BROWN, W. (20I7). Undoing the demos: neoliberalism's stealth revolution. Zone Books.

Butler, J. \& Athanasiou, A. (2013). Dispossession: the performative in the political. Cambridge: Polity Press.

Calvino, J. (2009). A instituição da religião cristã. Tradução de O. J. de Moraes Jr. e E. C. Sartorelli. São Paulo: Unesp.

CoHen, G. (1995). Self-ownership, freedom and equality. Cambridge University Press.

Colliot-Thélène, C. (20II). La démocratie sans demos. Paris: PUF. 
Esposito, R. (2013). Due: la macchina della teologia politica e il posto del pensiero. Roma: Einaudi.

EsPOSITO, R. (2002). Imunitas: protezione e negazione della vita. Turim: Einaudi.

EsPOSITO, R. (20I4). Le persone e le cose. Roma: Einaudi.

DERRIDA, J. (2003). Voyous: deux essais sur la raison, Paris: Galillée.

Hegel, G.W.F. (1992). Fenomenologia do Espírito. Tradução de P. G. de Meneses. Petrópolis: Vozes.

HegEL, G.W.F. (1970). Grundlinien der Philosophie des Rechts. Frankfurt: Suhrkamp.

HeGEL, G.W.F. (1986). Vorlesungen über die Philosophie der Geschichte. Frankfurt: Suhrkamp.

KANT, I. (20I6). Crítica da razão prática. Tradução de M. Hulshof. Petrópolis: Vozes.

LACAN, J. (2000). Le séminaire VIII: Le transfert. Paris: Seuil.

LAClAU, E. (2015). A razão populista. São Paulo: Três Estrelas.

LOCKE, J. (2003). Two Treatises of Government. Cambridge: Cambridge University Press.

MaCPHERSON, C. R. (1993). The theory of possessive individualism. Oxford: Oxford University Press.

MarX, K. (2000). “Die britische Herrschaft in Indien”, In: Marx Engels Gesammtausgabe, Bande I/I2. Berlin: De Gruyter.

NozICK, R. (1974). Anarchy, state and utopia, Nova York: Basic Books.

Overton, R. (1998). "An arrow against all tyrants”. i2 out. I646. In: The English Levellers (Cambridge Texts in the History of Political Thought), Cambridge: Cambridge University Press, pp. 54-72.

Prado JR., B. (20I7). Ipseitas. Belo Horizonte: Autêntica.

Rousseau, J-J. (2006). Du contrat social. Paris: Pleiade.

SAFATle, V. (20I6). "Para além da sexualidade: Foucault e a liberdade como autopertencimento”, In: NOVAES, A. Mutaçôes: entre dois mundos. São Paulo: Edições Sesc, pp. 345-369.

SCHneEWInd, J. (200I). A invenção da autonomia. Tradução de M. F. Lopes. São Leopoldo: Editora Unisinos.

Viveiros de Castro, E. (20I7). Metafísicas canibais. São Paulo: Cosac e Naify.

ZAHARIJEVIC, A. Against individual: who qualifies as "one"? [no prelo]. 